\title{
Year ends with Europe still divided by nationalism
}

EUROPEAN nationalism, which set Europe back twice this century in two world wars, could do so a third time, but this time on the economic stage. Pessimists - perhaps realists - have long signalled that the European economy is in rapid relative decline, compared not only with the United States and Japan but with all the growing economies of the Pacific, and that the currency of real economic exchange and prosperity is becoming increasingly sophisticated and technological. Meanwhile, the Pacific countries surpassed Europe by $\$ 2,000$ million as a trading partner of the United States as long ago as 1980 , and the gap had already risen to $\$ 26,000$ million by 1983 .

Yet European governments and administrations are still dragging their feet over the coordination of Europe's divided, inefficient, talent-wasting national research and development which should lead to new products and markets. The cancellation of the final council of research ministers' meeting of 1986 on 22 December without agreement on the European Commission's framework programme for research and development has left Europe without any coordinated plans for development. The new Belgian presidency of the decision-making European Council of Ministers thus begins this month with a huge task: to reach agreement on European research.

Perhaps Belgium, with its profound historical experience of European divisions, can forge links where others have failed. But British officials, who have struggled to reach agreement among the 12 members of the European Community for the past six months, while Britain held the presidency of the European Council, can see no easy path of compromise open to the Belgians. The issue is money, a factor of two between the 7,735-million-ECU ( $£, 500$ million) five-year programme, a doubling of present spending, proposed by the Commission and supported, more or less, by all but Britain, France and West Germany, which would prefer no real increase in the budget. A reduced budget would certainly put a stop to the European Commission's plans to move Europe into a new phase of scientific and technological cooperation.

There will be "grave damage to Europe", says Umberto Colombo, who heads the Italian nuclear and alternative energy agency, ENEA, and is president of the Commission's scientific advisory panel and think-tank, CODEST, if the European Commission does not receive sufficient support. Colombo believes the Commission has made "a great leap forward" over the past five years in its research programmes, and that it should now be free to move at a faster pace. In support, he singles out the successes of ESPRIT (which got information technology companies talking to one another and researching on common problems), BRITE (new technologies for old industries), RACE (telecommunications) and the Commission biotechnology and 'stimulation' (academic exchange and cooperation) programmes. "Now is the time to build on that work and achieve a genuinely European science and technology community."

But it is no secret that national interests will be paramount. Britain, for example, will oppose the Commission's plans to coordinate and share big European marine research facilities such as ships and research stations while West Germany will refuse any substantial common telecommunications programme.

The latter involves the development of a Europe-wide 'integrated digital services network' to carry mixed voice, visual and computer information. With a European market base bigger than that of the United

\section{Prospects for 1987 Western Europe Robert Walgate in L ondon}

States and twice that of Japan, there is a great opportunity for the European telecommunications and electronics industries with their standards and technologies to establish a solid home base and then capture world markets.

The European RACE programme in telecommunications is designed to capitalize on this position and unite administrations, technology programmes and markets. West Germany's priority however, is to promote its own electronics leader, Siemens. And with the German post office already begining a ten-year programme to introduce integrated service exchanges throughout the country, the European Commission's RACE, a major component of the framework programme, is seen in West Germany as a means of easily tapping into German technology.

There is, however, encouragement in the form of Eureka, that ad hoc assembly of nominally market-oriented projects (now numbering 111 and worth $£ 4,000$ million over the next eight years) among European companies. The vitality of Eureka, which began as an initiative of President François Mitterrand of France, has surprised even Mitterrand (as he made clear in a recent speech). But it is a strange pot-pourri of projects, and there is no strong indication yet of how its typically

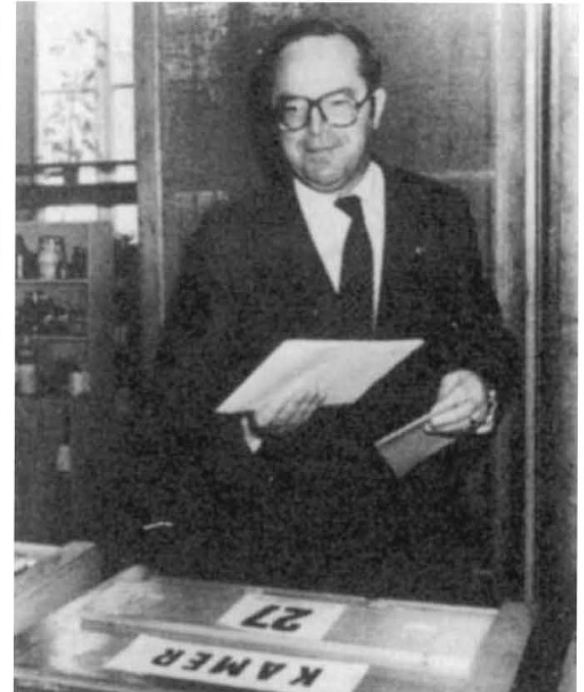

Next man in: Belgian prime minister Wilfred Martens, seen here voting in last October's general election, starts the year as EEC president. bi- and tri-partite programmes will open European markets.

Without a full European framework for upstream research and downstream regulations and markets, the fear is that Eureka may flourish only in the short term - as companies allow themselves hopes of new products and wider markets, only to be disappointed in the long term if deeper issues are not solved.

One of those upstream of Eureka is the creation of a 'researchers' Europe', an efficient framework for the movement of researchers around Europe at all levels; this is part of the Commission's framework programme, an extension of the present and successful 'stimulation programme'. But ministers, while paying lip service to greater movement and cooperation, have been reluctant to fund any increase in this programme, and recently wrecked Commission plans for accelerated student exchanges (the ERASMUS programme) by voting it no money. As a result of the ministerial penny-pinching, the Commission withdrew the proposal.

Another more optimistic possibility, though, is that Eureka will help develop a completely new structure for determining European educational, research, development, technology and marketing priorities at government level. A Eureka project on high-definition television, for example, and another on the 'intelligent vehicle' (the Prometheus project for road traffic management) have both set up working groups involving governments, industry and others to develop agreements on possible national purchasing and standards. Britain has also introduced a management training programme to underpin Eureka.

Eureka may thus appear in 1987 to be beginning to take the lead in European cooperation, and, if so, government, and the Commission, will be watched very closely to see how rapidly they can respond. 